\title{
Validation of a Sustainable Model for the Mining- Metallurgical Industry in Mexico ${ }^{+}$
}

\author{
Rosa Martínez ${ }^{1, *}$, Mariusz Bednarek ${ }^{2}$ and Urszula Zulawska ${ }^{2}$ \\ 1 Technological Institute of San Luis Potosi, National Technological of Mexico, Mexico City MEX 78437, \\ Mexico; m.rosaelia@gmail.com \\ 2 Faculty of Social Sciences, University of Lodz, PL 725-105-62-20 Łódź, Poland; mb@eventgroup.pl (M.B.); \\ zulawska@world.pl (U.Z.) \\ * Correspondence: m.rosaelia@gmail.com; Tel.: +52-444-829-7780 \\ + Presented at the 5th Ibero-American Congress on Entrepreneurship, Energy, Environment and \\ Technology -CIEEMAT, Portalegre, Portugal, 11-13 September 2019.
}

Published: 6 January 2020

\begin{abstract}
Mexico is identified in the world as a nation that produces a large amount of minerals that contribute to economic mobility. However, as a consequence of the mining activity, negative assumptions have been generated regarding the impact caused to the environment, since by nature, this industry tends to be aggressive in its processes. Therefore, it is considered a research study that offers a proposal for a sustainable model that is based on elements such as: literary foundations, sustainable universal principles and legislative parameters; and that, in addition, is supported by the best environmental practices, which lead to minimization or eradication of impacts or risks of environmental impact. The objective of this document is to describe the validation of the sustainable model for the mining-metallurgical industry in Mexico, through the design of qualitative research that is based on the integrated multiple case study method. Its scope is limited to the presentation of validation and other preliminary results, considering in future publications to provide specific results of the case studies and the implementation of the model.
\end{abstract}

Keywords: environmental management; sustainability; sustainable development; Mining-metallurgical Process

\section{Introduction}

The mining-metallurgical industry represents an important economic bastion, in 2017, which has allowed 120 countries to increase their foreign capital investment, productivity, exports and employment, which are then key factors that contribute to these countries' economic and financial improvement. In Mexico this industry is responsible for the production of 53 different minerals, which consist of: 11 metallic minerals and 42 non-metallic minerals. Around $70 \%$ of Mexico's territorial extension has favorable geological features that allow the development of mining projects; this makes it one of the most important mineral-producing countries worldwide [1].

The Mexican sub secretariat of Promotion and Environmental Regulation is in charge of regulating this industry's environmental impact by promoting an optimal environmental care [1]. This sub secretariat, for its operation within the mining-metallurgical industry presents detailed descriptions of the stages of the mining-metallurgical process, for its analysis in terms of environmental impacts, these being recorded in official reports as: Environmental Impact Manifests and Evaluation of Environmental Impact.

The stages of the mining-metallurgical process are [2]: (1) Exploration: the areas of interest are recognized, in order to confirm the physical and chemical characteristics that show that mineral deposits exist. (2) Exploitation: works designed to prepare and develop the area where there are 
mineral deposits, as well as activities aimed at extracting said minerals or substances from nature. (3) Concentration of minerals (metallurgy): works of preparation and treatment, smelting and refining of extracted mineral products, with the purpose of recovering minerals and substances in terms of purity (separation). (4) Closing: once the mining-metallurgical operation ends, the closure must be planned strategically, with the vision of reintegrating the property used to its natural or urban environment.

Each part of the mining-metallurgical process has a different magnitude of environmental risk during its execution. There is a notable disassembly between what every unit in this sector promotes as the main and most important parts of their management (Ecologic programs, sustainability, environmental responsibility, etc.). The results of these evaluations are occasionally noticeable, often being published by national news companies, affecting the communities' perception and allowing the growth of radical groups which present themselves as non-profit organizations.

As a result, there is a need to create a sustainability model that includes these different perspectives, which should be based on the legal, social and operational duties of these miningmetallurgical units. This model is founded on four pillars: (1) a theoretical construct that takes in mind sustainability and the new sustainable development trends in the world, (2) universal principles that allow us to describe this sector's environmental strategy, (3) parameters that obey the country's laws and, (4) best practices based on the operations and productive processes of the units. The objective of this document is to show the bases of the sustainability model to reduce and avoid environmental impact risk and environmental impact.

\section{Theoretical Basis}

The elements that constitute the base of the new sustainable model must be properly articulated in order to consolidate new execution parameters in each industry unit. Each of these units will arrange supportable and provable information according to national and international agreements, productive processes' results and the environmental care strategies that each of these mining units is implementing. This environmental sustainability model gives the sector companies theoretical and methodological tools to minimize or eradicate impact risks while allowing the productive stage of each of the units. It is organized into four elements:

- The first element that is considered as a theoretical basis is the discussion between Sustainability and Sustainable Development. This is the cause of a possible conflict of definition in these concepts, in their execution. They can be synonymous, however, in their implementation: sustainability originates in the management, while sustainable development is part of the practices [3].

- Sustainability is part of strategic planning, focusing on ecological and spatial impacts, the latter (1) the supply (consumption of water, energy, fuels) and (2) sanitation (solid waste, wastewater, toxic gases). It also considers aspects of the problems (scientific and ethical) and, at the same time, considers the limits and maximum possible requirements to maintain the standard of living and economic development [3]. Sustainable Development, is an alternative principle to generate a balance between economic growth, social justice and the environment; therefore, it means that there are necessary programs in which the inclusion of human habits tend to the equity of consumerism and the creation of services and opportunities and, more efficient production and operation processes that take advantage of the use of renewable resources [4].

- Therefore, it is considered from the analysis of these concepts, a research own definition: "Sustainable refers to environmental practices endorsed by legislation through normativity, which allow industry and society to guarantee natural resources to future generations; these practices are integrated into strategic plans from business management".

- Regarding the second element, governments around the world considered sustainable development efforts and, together, led the economic, social and environmental challenges. As a result, they have proposed 17 Sustainable Development Goals (SDGs), which emerge within the framework of a United Nations Congress and are raised in the "Agenda 2030", among these, there are at least six that directly force practices for the benefit of the environment [5]: 
1. Clean water and sanitation

2. Industry, innovation and infrastructure

3. Sustainable cities and communities

4. Responsible production and consumption

5. Action for climate

6. Terrestrial and life ecosystems

Four of these objectives were considered in this project which become the main axis of the study and from now on they will be called Sustainable Principles, there are described at Table 1.

Table 1. Relationship of objectives of sustainable development and operating process of the miningmetallurgical sector. Source: own elaboration.

\begin{tabular}{|c|c|c|}
\hline $\begin{array}{l}\text { Sustainable } \\
\text { Principle }\end{array}$ & Description & $\begin{array}{l}\text { Goals that Apply to the Mining-Metallurgical } \\
\text { Sector }\end{array}$ \\
\hline \multirow{3}{*}{$\begin{array}{l}\text { Industry, } \\
\text { Innovation, and } \\
\text { Infrastructure }\end{array}$} & \multirow{3}{*}{$\begin{array}{l}\text { Growth and urbanization generate the } \\
\text { need for new investments in } \\
\text { sustainable infrastructures that allow } \\
\text { cities to be more resistant to climate } \\
\text { change and promote economic growth } \\
\text { and social stability. }\end{array}$} & $\begin{array}{l}\text { Develop reliable, sustainable, resilient and quality } \\
\text { infrastructures to support economic development and } \\
\text { human well-being. }\end{array}$ \\
\hline & & $\begin{array}{l}\text { Promote an inclusive and sustainable } \\
\text { industrialization; provide financial, technological and } \\
\text { technical support. }\end{array}$ \\
\hline & & $\begin{array}{l}\text { Increase scientific research and improve the } \\
\text { technological capacity of the sector. }\end{array}$ \\
\hline \multirow{3}{*}{$\begin{array}{l}\text { Sustainable Cities } \\
\text { and } \\
\text { Communities }\end{array}$} & \multirow{3}{*}{$\begin{array}{l}\text { Cities are required with opportunities, } \\
\text { access to services, energy, housing, } \\
\text { transportation and more facilities. } \\
\text { Cities are characterized as centers that } \\
\text { concentrate commerce, culture, } \\
\text { science, productivity, creativity, social } \\
\text { and economic development. }\end{array}$} & $\begin{array}{l}\text { Provide access to safe, affordable, accessible and } \\
\text { sustainable transport systems. }\end{array}$ \\
\hline & & $\begin{array}{l}\text { Increase inclusive and sustainable urbanization and } \\
\text { capacity for participatory, integrated and sustainable } \\
\text { planning and management of human settlements. }\end{array}$ \\
\hline & & $\begin{array}{l}\text { Reduce the negative environmental impact per capita } \\
\text { of cities, including paying special attention to air } \\
\text { quality and the management of municipal and other } \\
\text { types of waste. }\end{array}$ \\
\hline \multirow{3}{*}{$\begin{array}{l}\text { Responsible } \\
\text { Production and } \\
\text { Consumption }\end{array}$} & \multirow{3}{*}{$\begin{array}{l}\text { Create more and better things with } \\
\text { fewer resources, increasing net profits } \\
\text { by reducing resource utilization, } \\
\text { degradation and pollution, achieving } \\
\text { a better quality of life. Adoption of a } \\
\text { systemic approach to achieve } \\
\text { cooperation among participants: } \\
\text { companies, consumers, government, } \\
\text { organisms, researchers, scientists. }\end{array}$} & $\begin{array}{l}\text { Achieve sustainable management and efficient use of } \\
\text { natural resources. }\end{array}$ \\
\hline & & $\begin{array}{l}\text { Achieve environmentally sound management of } \\
\text { chemicals and all wastes throughout their life cycle } \\
\text { and reduce their release to the atmosphere, water and } \\
\text { soil in order to minimize their adverse effects on } \\
\text { human health and the environment. }\end{array}$ \\
\hline & & $\begin{array}{l}\text { Significantly reduce the generation of waste through } \\
\text { prevention, reduction, recycling and reuse activities. }\end{array}$ \\
\hline \multirow{3}{*}{$\begin{array}{l}\text { Terrestrial and } \\
\text { Life Ecosystems }\end{array}$} & \multirow{3}{*}{$\begin{array}{l}\text { Nature, seen as ecosystems, occupies } \\
30 \% \text { of the earth's surface, which } \\
\text { provides food security and shelter, } \\
\text { fundamental to combat climate } \\
\text { change, by protecting biological } \\
\text { diversity. The challenges for } \\
\text { sustainable development are: } \\
\text { deforestation and human } \\
\text { desertification, through the } \\
\text { restoration of ecosystems. }\end{array}$} & $\begin{array}{l}\text { Ensure the conservation, restoration and sustainable } \\
\text { use of terrestrial ecosystems and inland freshwater } \\
\text { ecosystems and their services, particularly forests, } \\
\text { wetlands, mountains and arid zones. }\end{array}$ \\
\hline & & $\begin{array}{l}\text { Promote the implementation of sustainable } \\
\text { management of all types of forests, stop deforestation, } \\
\text { recover degraded forests and significantly increase } \\
\text { afforestation and reforestation. }\end{array}$ \\
\hline & & $\begin{array}{l}\text { Adopt urgent and significant measures to reduce the } \\
\text { degradation of natural habitats, stop the loss of } \\
\text { biodiversity and protect threatened species and } \\
\text { prevent their extinction. }\end{array}$ \\
\hline
\end{tabular}

The companies of the mining sector, like the rest of the industries, are attached to the regulations which are described for evaluation and monitoring, in the legislation of the country, this became the third element of the study. The normativity analysis, takes the environmental aspect to mitigate impacts that is why companies in the mining sector must describe the impact risks in official reports. 
On this basis, the agencies that belong to the government sector assess their veracity in the document [6]: Environmental Impact Manifestations (EIM).

This report describes 109 parameters, of which 16 have been selected to carry out this research: useful lifetime, technical manager, nature of the project, dimensions, land use, urbanization of the area, site preparation, construction of works operation and maintenance, abandonment, explosive use, generation and management of waste, management infrastructure and waste disposal, abiotic aspects, biotic aspects and landscape [7].

At the Table 2, there are shown these legislative parameters with their respective description, which represents why it is directly related to sustainable principles:

Table 2. Relationship of environmental parameters and their description; based on Environmental Impacts Manifest. Source: own elaboration.

\begin{tabular}{|c|c|}
\hline $\begin{array}{c}\text { Environmental } \\
\text { Parameters }\end{array}$ & Description of the Environmental Parameter According to the EIM \\
\hline Usefull Lifetime & $\begin{array}{l}\text { The stages are described with justification and precision, this } \\
\text { implies planning at the end of the productive activities and } \\
\text { managing according to the location and characteristics of the mining } \\
\text { unit in any of its processes. }\end{array}$ \\
\hline Technical Support & $\begin{array}{l}\text { It is required to have a specialist to carry out the study that will } \\
\text { support the presentation of MIA to the authorities. This ensures that } \\
\text { remediation will be reliable, since this person concentrates his } \\
\text { activities on such preparation. }\end{array}$ \\
\hline Nature of the Project & $\begin{array}{l}\text { It must be justified if it is a new mining work, expansion, expansion, } \\
\text { modification, replacement, rehabilitation of infrastructure or other } \\
\text { situation to identify present and future environmental elements. } \\
\text { Also indicate the stage of the mining process in question: } \\
\text { exploration, exploitation, benefit, remediation or closure. }\end{array}$ \\
\hline Dimensions & $\begin{array}{l}\text { Specify the total area; It is necessary to consider all the territorial } \\
\text { extension, to describe the possible risks that are run: rivers, } \\
\text { mountains, valleys, lagoons, to be able to document it to mitigate } \\
\text { the impact in the remediation stage. }\end{array}$ \\
\hline Land use & $\begin{array}{l}\text { It is required to specify the use of land in the area: agricultural, } \\
\text { livestock, forestry, human settlement, industrial, tourism, mining, } \\
\text { protected, without obvious use, to describe the use of water } \\
\text { settlements, which may be: public supply, recreation, fishing, } \\
\text { aquaculture. With this, it is expected that the alteration suffered will } \\
\text { not change the ecosystem in essence, neither during the operation } \\
\text { nor in the remediation. }\end{array}$ \\
\hline Urbanization of the area & $\begin{array}{l}\text { Availability of basic and support services near the unit. Manage the } \\
\text { operation to obtain, build or operate the infrastructure. This } \\
\text { includes access roads, drinking water, electricity, drainage; } \\
\text { wastewater treatment, telephone lines. }\end{array}$ \\
\hline Site Preparation & $\begin{array}{l}\text { Describe in detail and objectively the design of each of the stages of } \\
\text { the mining process, to know and associate the effect of this design } \\
\text { with the minimization of impacts to the environment and the } \\
\text { remediation that will be developed based on mitigating or avoiding } \\
\text { them. }\end{array}$ \\
\hline Construction of Works & $\begin{array}{l}\text { Describe in detail the works to be built at each stage of the mining } \\
\text { process, as remediation, recovery of territorial extension, land use } \\
\text { and water settlements will be necessary. In this way, the } \\
\text { remediation of ditches, tunnels, wells, pits, dynamite sites, deposits } \\
\text { of inert and fertile material, leaching yards, dams will be analyzed } \\
\text { in detail. }\end{array}$ \\
\hline
\end{tabular}


Description of programs of operation and maintenance of the
facilities, including type of services provided, technology related to

Maintenance the emission of and control of liquid, solid or gas waste, type of repair to systems, equipment, weed control, harmful fauna and their methods of control.

methods of control. technical feasibility studies. Rehabilitation, compensation and restitution measures will be considered. This will provide environmental impacts and availability of resources to carry it out.

\begin{tabular}{|c|c|}
\hline Abandonment & $\begin{array}{l}\text { technical feasibility studies. Rehabilitation, compensation and } \\
\text { restitution measures will be considered. This will provide } \\
\text { environmental impacts and availability of resources to carry it out. }\end{array}$ \\
\hline Use of Explosives & $\begin{array}{l}\text { Detail quantity and territorial extension that will be impacted, since } \\
\text { the risks of seismic vibrations that are generated can cause } \\
\text { permanent or irreversible damage. In addition, the damaged image } \\
\text { will be considered in the remediation. }\end{array}$ \\
\hline $\begin{array}{c}\text { Waste Generation and } \\
\text { Management }\end{array}$ & $\begin{array}{l}\text { This description includes the generation and disposal of solid waste, } \\
\text { liquids and emissions, and also the infrastructure for their } \\
\text { management. This category includes sanitary landfills, wastewater } \\
\text { treatment plants, recycling, confinement and their sufficiency. The } \\
\text { territorial extensions that these occupy have a strong environmental } \\
\text { impact. }\end{array}$ \\
\hline $\begin{array}{l}\text { Infrastructure for Waste } \\
\text { Management and } \\
\text { Disposal }\end{array}$ & $\begin{array}{l}\text { Identify infrastructure services for management and final disposal } \\
\text { of waste in the locality: landfill, wastewater treatment, separation, } \\
\text { handling, treatment, recycling or confinement of waste. Check if } \\
\text { they are sufficient for the present, future and even other projects } \\
\text { demand. }\end{array}$ \\
\hline Abiotic Aspects & $\begin{array}{l}\text { In this parameter, will be described aspects such as: type of climate, } \\
\text { climatological phenomena (earthquakes, for example to consider the } \\
\text { use of explosives), lithological characteristics (vegetation mapping), } \\
\text { morphological characteristics (hills, slopes, depressions), relief } \\
\text { characteristics (topographic plane), presence of faults and } \\
\text { fracturing, susceptibility (earthquakes, volcanoes); hydrological } \\
\text { resources of the area (surface and underground). }\end{array}$ \\
\hline Biotic Aspects & $\begin{array}{l}\text { In this parameter, detailed aspects of: vegetation (indicator } \\
\text { representing environmental conditions), wildlife (terrestrial, } \\
\text { aquatic) must be described. It is not only considered to list them, but } \\
\text { to make deep interpretations considering: seasonality (periods of } \\
\text { life), distribution, taxonomic difficulty (classification of species). }\end{array}$ \\
\hline Landscape & $\begin{array}{l}\text { The visibility (topographic aspects: altitude, orientation, slopes), } \\
\text { landscape quality (normally morphological intrinsic characteristics), } \\
\text { visual quality (lithology, bodies of water), scenic background } \\
\text { quality (diversity of vegetation, altitude) will be described in detail. } \\
\text { Fragility is also described (ability to absorb changes). }\end{array}$ \\
\hline
\end{tabular}

\section{Sustainable Model in the Mining-Metallurgical Industry}

In the following scheme Figure 1, the structure that acquires the proposed sustainable model is shown:

1. E1, represent the literal concepts of Sustainability and Sustainable Development, and with the basis of a theoretical discussion, it let the research to present an own way to express them.

2. E2, refers to the second element, that involucrate the Theoretical Basis that gives the principal axis to the research: universal principles of sustainability.

3. E3, refers to the third element, this is the theoretical basis that the Law in Mexico, brings to the companies of the mining sector, obligations

4. E4-N, the fourth and new element is presented as the first collaboration of this research as added value by this research. It contains the work field that included the construction of data collection instruments. 


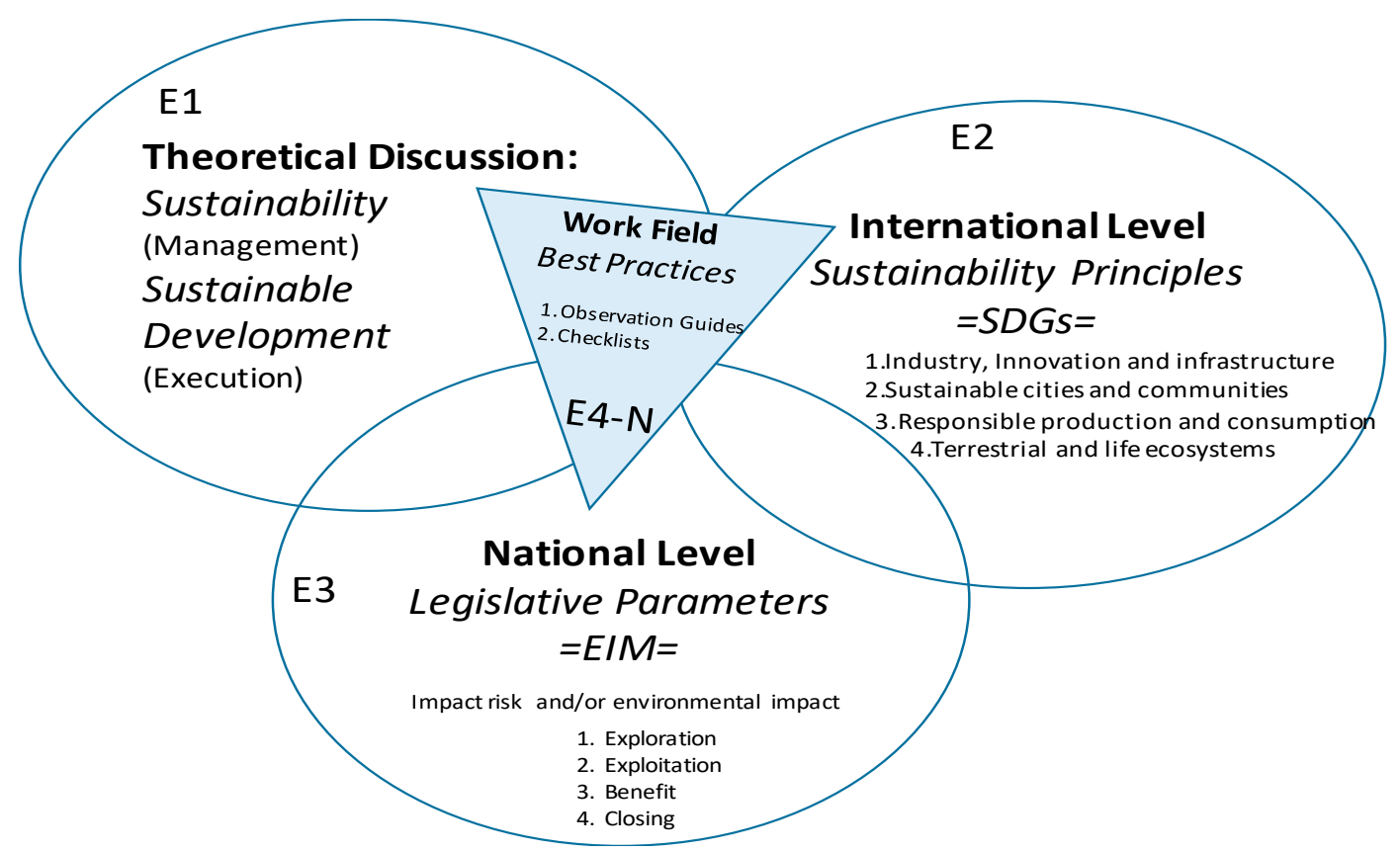

Figure 1. Sustainable Model and its elements for the Mining-metallurgical Industry. Source: own elaboration.

The proposed sustainable model must be validated to demonstrate its effectiveness, so it was implemented in units that belong to the mining-metallurgical sector through an appropriate research method. Individual information is complemented with the rest of the units and, the result of best practices constitutes the fourth element of the model.

\section{Methodological Basis}

A qualitative research method was designed: integrated multiple case study [8], which had an emphasis on an interpretive constructivist paradigmatic perspective. Through a selection of units of analysis, four being chosen for convenience [9].

The case study allowed an alignment with the four elements described above. In addition, a participatory observation was used as a non-evaluative data collection strategy, to describe it attached to reality [9].

Observable elements and unobservable elements were considered. The instruments used to obtain the information were: observation guide, documentary compilation, interview and checklist. These were built based on the analysis of official documents, reports and sessions with experts in the fields of mining and the environment. They were subjected to pilot tests to facilitate their handling in the field work and in the adequate registration of the information obtained.

Following the methodology with the approach that Yin [10] proposes, each case study in each unit of analysis accorded with the systematically planned stages, among which three main ones are considered:

1. Preoperative stage, which includes literary support, construction of instruments for the data collection and programming;

2. Stage of field work, which included the application of the instruments created after a interview and several visits to the units.

3. Stage of analysis and interpretation, in which the participation of experts in mining and environmental matters to carry it out was considered.

Once the information from the analysis units was obtained, the data were triangulated, linking them with the elements of the model (conceptualization, sustainable principles and legislative parameters). This activity provided the opportunity to make comparisons in environmental activities and programs [11], which served to formalize a proposal for a guide to best practices. 
The validation of the model follows compliance with some criteria of quality, validity or rigor of qualitative research [9]. Every criteria was evaluated conform the case study took place at the units of analysis:

1. Dependence refers to the consistency of the data

2. Credibility is related to the validity of the constructions and the content

3. Transfer is the applicability of the results

4. Confirmation, which is measured by minimizing the biases of the researchers.

\section{Results}

The analysis units belong to representative companies of the mining-metallurgical sector, defining them as: (1) mines, with their own characteristics and specific geographical location, and (2) refineries, companies in the sector that provide continuity to the metallurgical process once the extraction stage of the mines ends. The Table 3, presents the selection that conform this integrated multiple case study, according to the transfer criteria.

Table 3. Unit of analysis for the Multiple Integrated Case Study. Source: own elaboration.

\begin{tabular}{ccccc}
\hline Classification & $\begin{array}{c}\text { Name of } \\
\text { the Unit }\end{array}$ & Corporate & Mineral Extracted OR Processed & $\begin{array}{c}\text { Location } \\
\text { Trend/Region }\end{array}$ \\
\hline Underground Mine & MSJ & ASM & $\begin{array}{c}\text { Silver and lead, Concentrate, } \\
\text { (metallic) }\end{array}$ & Trend Ag-Au-Pb-Zn \\
\hline Open Pit Mine & LL & EMM & $\begin{array}{c}\text { Feldspar Concentrate (non- } \\
\text { metallic) }\end{array}$ & South central region \\
\hline Refinery & REZ & GIMM & Zinc, Sulfuric Aid & North central region \\
\hline Unit in Closing & MSX & NGI & Gold (dore), silver & Trend Ag-Au-Pb-Zn \\
\hline
\end{tabular}

Taking into account the credibility criteria through the validity of the content, once the four case studies were carried out, a review of the literary foundations was made in relation to the risks of impact on the productive stages of the sector and the information that units provided.

In the Table 4, the impacts or risks of the environmental impact are listed, as a result of the observable elements in the analysis units.

Table 4. Impact risks and environmental impacts categorized by phase of the process and by sustainable principle. Source: own elaboration.

\begin{tabular}{|c|c|c|c|c|}
\hline \multirow{2}{*}{$\begin{array}{c}\text { Sustainable } \\
\text { Principle }\end{array}$} & \multicolumn{4}{|c|}{ Stages of the Mining-Metallurgical Process } \\
\hline & Exploration & Exploitation & Concentration & Closing \\
\hline 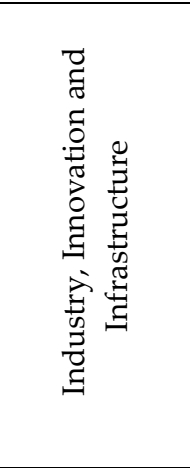 & $\begin{array}{l}\text { 1. Construction of } \\
\text { roads for } \\
\text { exploration } \\
\text { machinery. } \\
\text { 2. Construction of } \\
\text { squares. } \\
\text { 3. Water use. } \\
\text { 4. Maintenance of } \\
\text { equipment in the } \\
\text { field, use of } \\
\text { supplies. }\end{array}$ & $\begin{array}{l}\text { 1. Displacement of } \\
\text { material in the open } \\
\text { sky and in } \\
\text { underground } \\
\text { developments. } \\
\text { 2. Formation of sites } \\
\text { 3. Training of } \\
\text { mounds. } \\
\text { 4. Construction of } \\
\text { workshops for } \\
\text { services. }\end{array}$ & $\begin{array}{l}\text { 1. Obtaining tailings } \\
\text { as waste. } \\
\text { 2. Use and } \\
\text { containment of } \\
\text { chemical reagents. } \\
\text { 3. Excessive use and } \\
\text { contamination of } \\
\text { water. } \\
\text { 4. Spills. }\end{array}$ & $\begin{array}{l}\text { 1. Technical } \\
\text { studies and } \\
\text { incomplete } \\
\text { supervision } \\
\text { 2. Rules not } \\
\text { fulfilled. }\end{array}$ \\
\hline
\end{tabular}




\begin{tabular}{|c|c|c|c|c|}
\hline 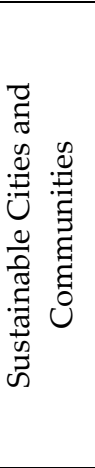 & $\begin{array}{l}\text { 1. Construction of } \\
\text { roads and steps. } \\
2 \text {. Limited } \\
\text { economic resource } \\
\text { and, on the other } \\
\text { hand, not limited. }\end{array}$ & $\begin{array}{l}\text { 1. Creation of non- } \\
\text { governmental } \\
\text { organizations } \\
\text { (stakeholders). } \\
\text { 2. Use of explosives } \\
\text { without prior } \\
\text { technical studies. } \\
\text { 3. Construction of } \\
\text { roads without } \\
\text { considering } \\
\text { populations. }\end{array}$ & $\begin{array}{l}\text { 1. Creation of non- } \\
\text { governmental } \\
\text { organizations } \\
\text { 2. Small miners } \\
\text { without economic } \\
\text { resources, do not } \\
\text { support the } \\
\text { community. }\end{array}$ & $\begin{array}{l}\text { 1. Creation of } \\
\text { non- } \\
\text { governmental } \\
\text { organizations } \\
\text { 2. Limited } \\
\text { economic } \\
\text { resources do not } \\
\text { support } \\
\text { community. }\end{array}$ \\
\hline 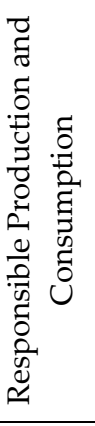 & $\begin{array}{l}\text { 1. Displacement of } \\
\text { material by } \\
\text { exploration work. } \\
\text { 2. Approach the } \\
\text { water table }\end{array}$ & $\begin{array}{l}\text { 1. Construction of } \\
\text { luminaries. } \\
\text { 2. Construction of } \\
\text { underground mine } \\
\text { shots. } \\
\text { 3. Construction of } \\
\text { tunnels. } \\
\text { 4. Extraction of } \\
\text { gases into the } \\
\text { atmosphere. }\end{array}$ & $\begin{array}{l}\text { 1. Excessive water } \\
\text { consumption. } \\
\text { 2. Storage of } \\
\text { obsolete reagents in } \\
\text { the concentration } \\
\text { plant and } \\
\text { laboratories. }\end{array}$ & $\begin{array}{l}\text { 1. Water } \\
\text { pollution. } \\
\text { 2. Construction } \\
\text { of tailings dam } \\
\text { without slopes }\end{array}$ \\
\hline 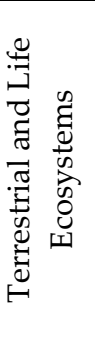 & $\begin{array}{l}\text { 1. Construction of } \\
\text { roads. } \\
\text { 2. Construction of } \\
\text { squares. } \\
\text { 3. Use of oil. }\end{array}$ & $\begin{array}{l}\text { 1. Formation of } \\
\text { land. } \\
\text { 2. Formation of } \\
\text { mounds. } \\
\text { 3. Construction of } \\
\text { industrial buildings, } \\
\text { infrastructure. }\end{array}$ & $\begin{array}{l}\text { 1. Obtaining tailings } \\
\text { as waste. }\end{array}$ & $\begin{array}{l}\text { 1. Infrastructure } \\
\text { construction. } \\
\text { 2. Insufficient or } \\
\text { no economic } \\
\text { programming } \\
\text { for closing and } \\
\text { remediation } \\
\text { stages. }\end{array}$ \\
\hline
\end{tabular}

This information was ordered according to the results of each unit of analysis and serves as the basis for creating the "Best practices" guide, since special attention is given to risk prevention when any of the situations mentioned above arises.

The Sustainable Model for the Mining-metallurgical Industry in Mexico, was validated, once each case study was carried out. This validation is presented based on the four quality criteria proposed by qualitative research [9].

1. Dependency, is consolidated when experts in the mining-environmental field, reviewed, analyzed and interpreted the information obtained from each unit of analysis, having reached congruent and similar interpretations.

2. Credibility or "maximum validity", whose conjunctions of meanings and experiences are linked to the research approach, being the proposals, suggestions and corrections of advisers in research methodology and mining technical advisors, who provide the relevant guidance to avoid trends and, therefore, generate quality required to accept this criterion. It also validates constructions and contents.

3. Transfer refers to the application of the results, in this case the sustainable model in other scenarios. This criterion was validated once the model was implemented in four different units, according to its own characteristics. The possibility of replicating it in more mining-metallurgical units is part of the general objective of the formal research that supports this document.

4. Confirmation, validated by the participation of the General Managers, Bosses, Managers or Persons Responsible for the "environment" of the analysis units, who guided the veracity of the responses, showed evidence and remained attentive to the interpretations that the researcher and Experts have described about the information they provided.

The results of the analysis units are expressed in terms of compliance or non-compliance with the sustainable principles and the effectiveness of the legislative parameters, analyzed from the 
perspective of observable impacts and unobservable impacts. Prepared and planned remediation activities are described, as well as the necessary budget items and whether they have been considered over time.

\section{Conclusions}

The general perception of the surrounding community and the urbanization works that have been carried out or, planned to be carried out are contemplated. It is linked to the objectives of each principle, where descriptions of the activities to achieve it are made and emphasis is placed on erroneous activities that depart from the objectives.

In addition, each unit, with its different characteristics, has a tendency for more elaborate and effective practices than others, which allowed the formalization of the best practices guide, which is under review.

This guide is intended to strengthen alternative or contingency plans, minimizing risks. As a tangible result, the attention of the personnel of the units is captured through the adaptation of the expression of sustainability, incorporating it into the evaluated principles and the model itself.

\section{Intellectual Property}

This research promotes the author to protect the sustainable model as original: elements and the figure that make it up.

Funding: This research received no external funding.

Acknowledgments: Mining Engineer Rodolfo Martinez Mendoza, his technical support and guidance through the process of this special industry sector. Mining Engineer specialist in environmental and safety of Mines Marco Navarro Gallegos, his environmental and legislative process support. Analysis Units Managements that let the research goes on.

Conflicts of Interest: The authors declare no conflict of interest.

\section{References}

1. Subsecretaría de Minería. Manual del Inversionista en el Sector Minero Mexicano; Secretaría de Economía: Mexico, 2017.

2. Coordinación General de Minería. Guía para Conocer las Etapas del Proceso Productivo para la Pequeña Minería; Secretaría de Economía: México, Mexico, 2014.

3. Naredo, J. Sobre el Origen, el uso y el Contenido del Término Sostenible. En la Construcción de la Ciudad Sostenible; Ministerio de Obras Públicas, Ed.; Transportes y Medio Ambiente: Spain, 1996.

4. UNEP. Avances y Progresos Científicos en Nuestro Cambiante Medio Ambiente; Programa de Naciones Unidas para el Medio Ambiente: Nairobi, Kenya, 2010; p. 80.

5. ONU. Agenda 2030 para el Desarrollo Sostenible; Organización de las Naciones Unidas: Vitacura, Chile, 2010.

6. Martínez, R.; Bednarek, M. Fundamentos para Construcción de Instrumento Ambiental para la Industria Minero-Metalúrgica. Revista de Arquitectura y Diseño, 2018; p. 6.

7. Martínez, R.; Rivera, P. Articulación de los Objetivos de Desarrollo Sostenible y la Legislación Ambiental en la Industria Minera. In Las Organizaciones en América Latina, 1st ed.; Hess Editor: Mexico, 2018.

8. Yin, R. Validez y Generalización en Futuras Evaluaciones de Casos de Estudio; COSMOS Corporation: Wentzville, MO, USA, 2013.

9. Hernandez, R. La Metodología de la Investigación; McGrawHill: México, 2014.

10. Yin, R. Case Study Research. In Design and Methods; SAGE: New York, NY, USA, 1994.

11. Massolo, L. Introducción a las Herramientas de Gestión Ambiental; Universidad Nacional de la Plata: La Plata, Argentina, 2015.

(C) 2020 by the authors. Licensee MDPI, Basel, Switzerland. This article is an open access article distributed under the terms and conditions of the Creative Commons Attribution (CC BY) license (http://creativecommons.org/licenses/by/4.0/). 